\title{
GROWTH AND REPRODUCTION OF THE DEEP-WATER ROSE SHRIMP, PARAPENAEUS LONGIROSTRIS (LUCAS, 1846) (DECAPODA, PENAEIDAE), IN THE SOUTHERN TYRRHENIAN SEA
}

\author{
BY
}

\author{
MARCO ARCULEO $^{1,4}$ ), SABRINA LO BRUTTO ${ }^{1}$ ), LEONARDO CANNIZZARO $^{2}$ ) and \\ SERGIO VITALE ${ }^{3}$ ) \\ $\left.{ }^{1}\right)$ Dipartimento STEBICEF, Via Archirafi 18, I-90123 Palermo, Italy \\ ${ }^{2}$ ) National Research Council (CNR) - Institute for Coastal Marine Environment (IAMC), \\ Capo Granitola, via del Faro 3, I-91021 Campobello di Mazara, Italy \\ 3) National Research Council (CNR) - Institute for Coastal Marine Environment (IAMC), \\ Mazara del Vallo, via Luigi Vaccara 61, I-91026 Mazara del Vallo, Italy
}

\begin{abstract}
From June 2006 to May 2007, monthly samples of Parapenaeus longirostris (Lucas, 1846) were collected on land from the landings of two different, although contiguous, fishing grounds exploited by the bottom trawl fisheries of the two fishing harbours of Terrasini and Porticello, located on the north-western coast of Sicily. Carapace length (CL) of the female and male deep-water rose shrimp in Terrasini ranged from 9 to $32 \mathrm{~mm}$ and 13 to $26 \mathrm{~mm}$, respectively, whereas in Porticello the length ranged from 8 to $31 \mathrm{~mm}$ and 13 to $26 \mathrm{~mm}$, respectively. The Von Bertalanffy Growth Function parameters for Terrasini females and males were $\mathrm{CL}_{\infty}=38.5 \mathrm{~mm}, K=0.65$ year $^{-1}$ and $\mathrm{CL}_{\infty}=$ $32.5 \mathrm{~mm}, K=0.85$ year $^{-1}$, respectively. For Porticello females and males, the parameters were $\mathrm{CL}_{\infty}=40 \mathrm{~mm}, K=0.60$ year $^{-1}$ and $\mathrm{CL}_{\infty}=30 \mathrm{~mm}, K=0.76$ year $^{-1}$, respectively. Analysis of maturity stages indicates that the deep-water rose shrimp is an asynchronous batch of almost continuous spawners, although one to two peaks of activity can be detected. In both fishing areas, the reproductive phase peaked twice, once in January and again from August to September. The sizes at first maturity $\left(\mathrm{CL}_{50 \%}\right.$ ) were 27.8 and $26.6 \mathrm{~mm}$ CL for Terrasini and Porticello, respectively.
\end{abstract}

Key words. - Parapenaeus longirostris, deep-water rose shrimp, growth, reproduction, Tyrrhenian Sea

\section{RIASSUNTO}

Campioni mensili di Parapenaeus longirostris (Lucas, 1846) sono stati raccolti allo sbarco di due differenti, sebbene limitrofe, marinerie della Sicilia nord occidentale (Terrasini e Porticello) nel periodo compreso tra Giugno 2006 e Maggio 2007. La lunghezza del carapace di maschi e femmine nella marineria di Terrasini era compresa rispettivamente tra 9 e $32 \mathrm{~mm}$ e tra 13 e $26 \mathrm{~mm}$, mentre nella marineria di Porticello risultava compresa tra 8 e $31 \mathrm{~mm}$ e tra 13 e $26 \mathrm{~mm}$. I parametri

${ }^{4}$ ) Corresponding author; e-mail: marco.arculeo@unipa.it

(C) Koninklijke Brill NV, Leiden, 2014

DOI:10.1163/15685403-00003334 
dell'equazione di Von Bertalanffy per i maschi e le femmine sono risultati, per la marineria di Terrasini, rispettivamente di $\mathrm{CL}_{\infty}=38,5 \mathrm{~mm}, K=0,65$ anno $^{-1} \mathrm{e} \mathrm{CL}_{\infty}=32,5 \mathrm{~mm}, K=0,85$

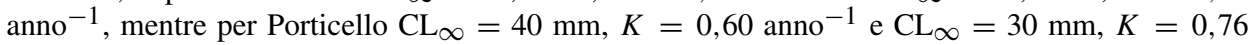
anno $^{-1}$. L'analisi della maturità gonadica ha evidenziato che in ogni mese e in entrambe le marinerie gli individui presentavano tutti gli stadi di maturità con due picchi riproduttivi coincidenti con il mese di Gennaio e con quelli di Agosto-Settembre. La taglia di prima maturità $\left(\mathrm{CL}_{50 \%}\right)$ è risultata di 27,8 and 26,6 mm LC per Terrasini e Porticello.

Parole chiave. - Parapenaeus longirostris, gambero rosa, crescita, riproduzione, Tirreno

\section{INTRODUCTION}

The deep-water rose shrimp, Parapenaeus longirostris (Lucas, 1846) is an epibenthic decapod crustacean with a wide geographical distribution from the eastern Atlantic to the Mediterranean Sea (Holthuis, 1987). In the Mediterranean, it is more abundant in the sandy-muddy depths between 100 and $400 \mathrm{~m}$ (Fischer et al., 1987; Holthuis, 1987), although its depth range is between 20 and $900 \mathrm{~m}$ (Tom et al., 1988; Politou et al., 2005). The bathymetric distribution of the deepwater rose shrimp is a matter of discussion, with several authors reporting a sizedependent bathymetric distribution, with adults deeper than juveniles (Froglia, 1982; Mori et al., 1986; Ardizzone et al., 1990), although the occurrence of "adults" is also reported from the outer shelf, and conversely, the presence of recruits $(<15 \mathrm{~mm})$ and juveniles in the epi-bathyal layer (Politou et al., 2000; Rinelli et al., 2004, 2005; Bilgin et al., 2009; Kapiris et al., 2013).

The high economic importance of this species, often fundamental in the market of several fishing fleets in the Mediterranean Sea (CBI, 2010), and its high exploitation level recorded in some fishing grounds of the Mediterranean, have led to increased interest in this species and development of several national (Relini, 2000) and international scientific research programmes (Relini et al., 2008). In fact, this shrimp is exploited in several fishing grounds all over its geographical range, with a large fishing fleet exploiting this resource in Italian, Spanish, Greek and Tunisian waters. In Italian waters, deep-water rose shrimp are most abundant in the Sicilian Channel and the Ionian Sea. Conversely, they are found in much lower densities in the Ligurian Sea and in the northern part of the Adriatic Sea (Levi et al., 1995; Abellò et al., 2002). In particular, the Expert Working Group (EWG) on assessment of Mediterranean Sea stocks reported on the state of the deep-water rose shrimp stock in the South Tyrrhenian Sea (Geographical Sub-Area, GSA 10 of the General Fisheries Commission for the Mediterranean, GFCM) highlighting that "the absence of proposed and agreed precautionary management references, EWG 13-09 is unable to fully evaluate the status of stock spawning biomass. Survey indices indicate a variable pattern of abundance $(\mathrm{n} / \mathrm{h})$ and biomass $(\mathrm{kg} / \mathrm{h})$ that was increasing in the last years" (STECF 13-22, 2013). 
During the last two decades, many aspects of both life history traits and fishery patterns have been investigated (Relini, 2000; Sobrino et al., 2005; Sobrino \& Garcia, 2007; Lo Brutto et al., 2013). However, to date some aspects on the biology of this species are still open and a thorough discussion is needed to understand to what extent the stock evolution is influenced by environmental factors, both on a local (currents, temperature, etc.) and mesoscale (e.g., North Atlantic Oscillation, $\mathrm{NAO}$ ). In fact, it appears that salinity and temperature along the Atlantic coast (Benchoucha et al., 2008) influence the spawning and catch and that, probably, in the Mediterranean Sea the differences in growth parameters and reproduction period present a possible geographical gradient. According to Arculeo et al. (1995 and references therein), Mura \& Cau (1989), and Margalef (1985), some differences in reproductive behaviour in the Mediterranean populations of the deep sea blue and red shrimp, Aristeus antennatus (Risso, 1816), are linked to the adaptive flexibility of the Mediterranean benthos; this hypothesis may be applicable to Parapenaeus longirostris as well, although this species occurs at lesser depths. Anyway, it is important to emphasize that the Mediterranean Sea is a semi-enclosed basin, warmer (only slight variation in temperature below the thermocline), saltier (also due to human activities such as the Nile damming) and, at least until some decades ago, very poor in nutrients (especially the eastern sector). Consequently, the dynamics of Mediterranean demersal crustaceans are open to discussion, since some authors maintain that it is more influenced by environmental fluctuations (for example, Abelló et al., 1988; Ungaro \& Gramolini, 2006) than fisheries activity (Sbrana et al., 2003; Ligas et al., 2011).

The main objective of the current study was to characterize growth parameters and reproduction trends computed during an occasional (one year) monitoring program and to gather spatial information which can be used within the "local management plans" recently implemented along the Sicilian coast (Regulation EC No. 1198/2006).

\section{MATERIAL AND METHODS}

From June 2006 to May 2007, monthly samples of deep-water rose shrimp were collected or purchased on land from the landings of two different, although contiguous, fishing grounds, exploited by the bottom trawl fisheries of the two fishing harbours of Terrasini and Porticello, located on the north-western coast of Sicily, GSA 10 (fig. 1). In general, GSA 10 has a high variety of biocenosis (sensu Peres \& Picard, 1964) with an area close to bottom trawling that amounts to approximately $20 \%$ of the total area comprised between the bathymetric of 10 and $800 \mathrm{~m}$. In particular, the northern coast of Sicily is characterized by a steep upper 


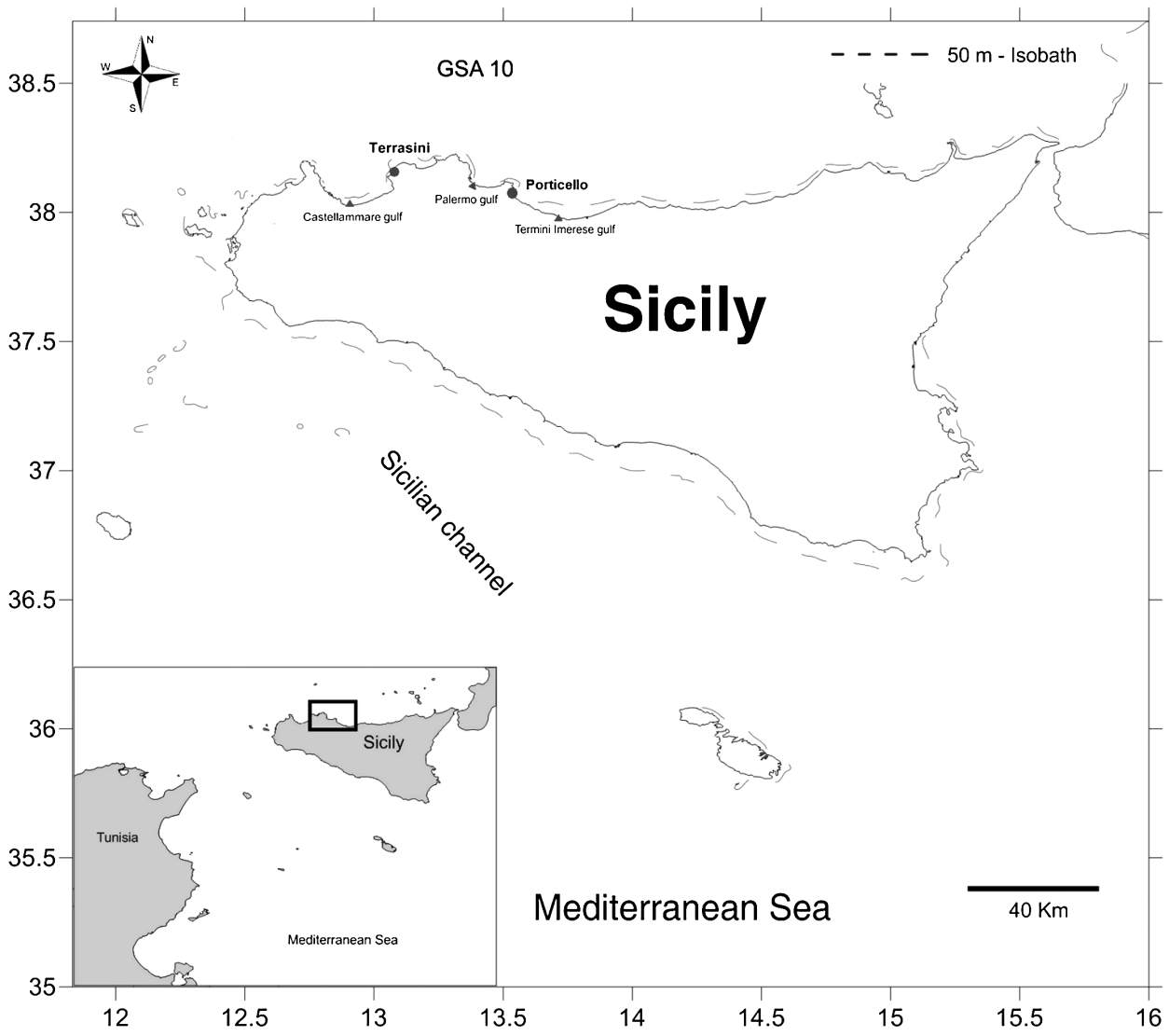

Fig. 1. Map of the sampling sites (Terrasini and Porticello) of Parapenaeus longirostris (Lucas, 1846).

slope that reaches an average depth of $500 \mathrm{~m}$ between 4 and $15 \mathrm{~km}$ from the coast (Spedicato et al., 1998). The trawl fleet of Terrasini works in the Castellammare Gulf, where until 1994 almost all the shelf and part of the epibathyal (200-500 m) of the Gulf was (at least nominally) permanently closed to bottom trawling (Rinelli et al., 2004), whereas the trawl fleet of Porticello works in the Palermo and Termini Imerese gulfs. The fishing capacity of Porticello is greater than that of Terrasini; in detail, Porticello has 76 trawlers with a mean gross tonnage of 26.61 (20.95 SD), while Terrasini has 11 trawlers with a mean gross tonnage of 71.60 (25.59 SD). Both fleets use the same mesh size ( $40 \mathrm{~mm}$ diamond) at the cod ends of the nets, and operate at the same depth (between 100 and $400 \mathrm{~m}$ ), with the fishing ground of Porticello about twice the size of the fishing ground of Terrasini.

Parapenaeus longirostris specimens were sexed and both carapace length (CL) and weight were recorded. CL was measured from the posterior margin of the orbit to the posterior edge of the carapace $(0.1 \mathrm{~mm})$; wet weight $(0.1 \mathrm{~g})$ was determined 
with a technical balance. The relationship between size and weight for each sex was determined by the following non-linear equation (Keys, 1928):

$$
W=a \times \mathrm{CL}^{b}
$$

where $W$ is the weight in $\mathrm{g}, \mathrm{CL}$ is the cephalothoracic length in $\mathrm{mm}$ and $b$ is the coefficient of allometry.

The special VBGF (Von Bertalanffy Growth Function) was used to estimate growth parameters using the Electronic Length Frequency Analysis I (ELEFAN I) function, by monthly data, included in FISAT II software (Gayanilo et al., 2005). The initial value of $\mathrm{CL}_{\infty}$ was computed according to the relationship obtained by Taylor (1962). Length-frequency Distributions (LFD) for both sexes were used to estimate modal class values using the Bhattacharya method. Each well-separated modal component, with a separation index $(\mathrm{SI})>2$, was assumed to be a single cohort. Frequency distributions at both fishing grounds were compared by sex. A Mann-Whitney $U$-test and a Kolmogorov-Smirnov test were used to compute the significance of the comparison between the frequency distribution at both sites by sex.

The maturity stage of females was evaluated based on the colour and size of the gonad according to a previously described macroscopic scale (stage I, gonad is transparent; stage II, gonad is beige-cream; stage III, gonad is clear-green; stage IV, gonad is dark green; Arculeo et al., 1992; De Ranieri et al., 1998; Sobrino et al., 2005; Bianchini et al., 2010), although recently both micro- and macroscopic stage assignments were updated (ICES WKMSC, 2010). The size at first maturity $\left(\mathrm{CL}_{50 \%}, \mathrm{CL}\right.$ at which $50 \%$ of the specimens in the population are mature, i.e., in stages III and IV) was estimated using specimens collected during the spawning period. A logistic curve was fitted using the least-squares method applied to a nonlinear fit (King, 1995). The overall sex ratio $(($ female/females + males $) \times 100)$ and the sex ratios by CL $(2 \mathrm{~mm})$ were also determined.

\section{RESULTS}

A total of 11620 specimens of Parapenaeus longirostris were examined from Terrasini and 12852 from Porticello. The CL of females and males in Terrasini ranged from 9 to $32 \mathrm{~mm}$ (average $25.87 \pm 3.58 \mathrm{~mm}$ ) and 13 to $26 \mathrm{~mm}$ (average $22.28 \pm 2.13 \mathrm{~mm}$ ), respectively, whereas in Porticello it ranged from 8 to $31 \mathrm{~mm}$ (average $24.65 \pm 3.93 \mathrm{~mm}$ ) and 13 to $26 \mathrm{~mm}(21.29 \pm 2.67 \mathrm{~mm})$, respectively (fig. 2).

The seasonal length-frequency distributions in both sexes and sampling sites did not differ significantly (Mann-Whitney $U$-test, $U=471, Z=0.1267, p \leqslant 0.05$; 


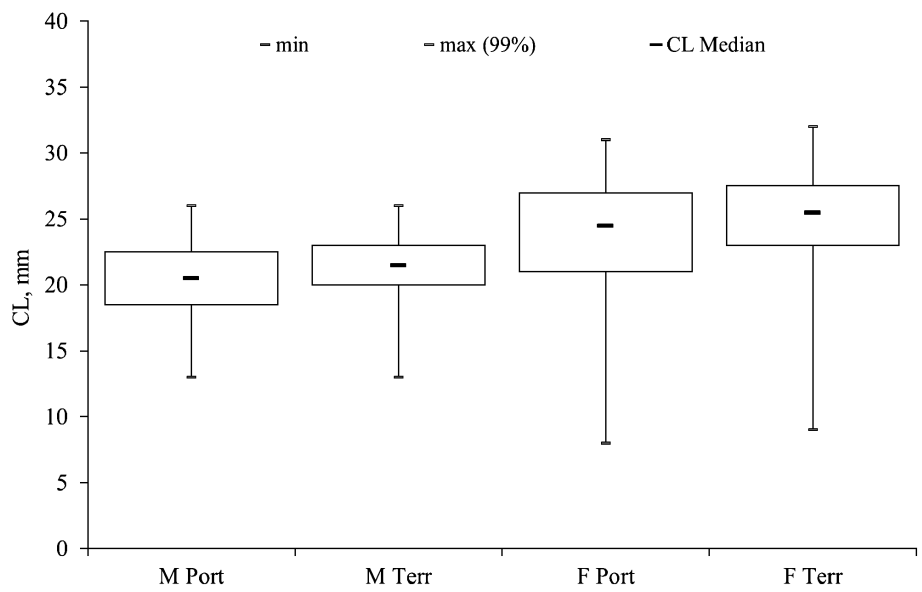

Fig. 2. Box-plot representation of the pooled length-frequency distribution of Parapenaeus longirostris (Lucas, 1846) by sex (M, males; F, females) and sampled harbour (Port, Porticello; Terr, Terrasini).

Kolmogorov-Smirnov test, $D=0.1290, p \leqslant 0.05)$, showing a greater presence of juveniles with $\mathrm{CL}<16 \mathrm{~mm}$ in the autumn and winter (fig. 3).

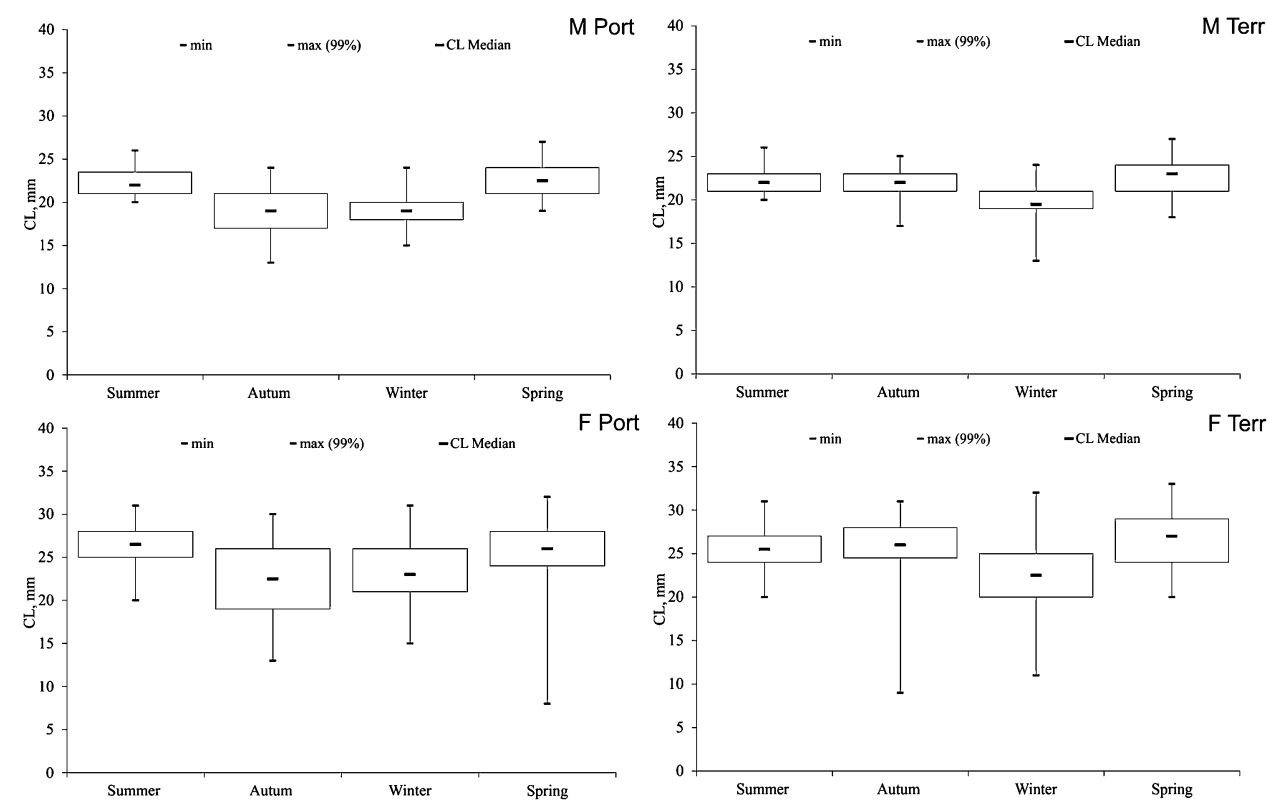

Fig. 3. Seasonal length-frequency distribution (median CL values) of Parapenaeus longirostris (Lucas, 1846) by sex (M, males; F, females) and sampled harbour (Port, Porticello; Terr, Terrasini). 
TABLE I

Size-weight relationship in Parapenaeus longirostris (Lucas, 1846) in the sampling sites

\begin{tabular}{lll}
\hline Size-weight relationship & Terrasini & Porticello \\
\hline$W=a \times \mathrm{CL}^{b}$ male & $y=0.0089 x^{2.117}$ & $y=0.0058 x^{2.267}$ \\
$N$ & $R^{2}=0.83$ & $R^{2}=0.88$ \\
$W=a \times \mathrm{CL}^{b}$ female & 248 & 276 \\
$N$ & $y=0.004 x^{2.399}$ & $y=0.004 x^{2.407}$ \\
$N$ & $R^{2}=0.89$ & $R^{2}=0.93$ \\
\hline
\end{tabular}

$N$, number of individuals.

The relationship between size and weight in each sex showed negative allometry, giving $b$ values significantly less than 3 , with a general tendency to be more pronounced in males than females (table I).

The modal components analysis (Bhattacharya's method on pooled LFD by sex and fishing ground) resulted in three for females and two for males in both sampling sites (table II).

The estimated VBGF parameters for Terrasini females and males were: $\mathrm{CL}_{\infty}=$ $38.5 \mathrm{~mm}, K=0.65$ year $^{-1}$ and $\mathrm{CL}_{\infty}=32.5 \mathrm{~mm}, K=0.85$ year $^{-1}$, respectively. For Porticello females and males, the parameters were $\mathrm{CL}_{\infty}=40 \mathrm{~mm}, K=0.60$

\section{TABLE II}

Results of the Bhattacharya's method to identify Parapenaeus longirostris (Lucas, 1846) modal components (annual cohort) by sex and sampled harbour

\begin{tabular}{lccc}
\hline Cohort & Computed mean & SD & SI \\
\hline Terrasini female & 23.85 & & \\
1 & 26.76 & 1.43 & n.a. \\
2 & 30.26 & 1.19 & 2.02 \\
3 & & 1.06 & \\
Porticello female & 17.67 & & n.a. \\
1 & 23.41 & 1.08 & 2.21 \\
2 & 28.06 & 2.66 & 2.03 \\
3 & & 1.93 & \\
Terrasini male & 15.25 & & n.a. \\
1 & 22.2 & 1.43 & 2.42 \\
2 & & 2.03 & n.a. \\
Porticello male & 16.16 & & 2.2 \\
1 & 21.54 & 1.32 & \\
2 & & 2.34 & \\
\hline
\end{tabular}

SD, standard deviation; SI, separation index; n.a., not available. 
TABLE III

Comparison of growth parameters for Parapenaeus longirostris (Lucas, 1846) available in the literature

\begin{tabular}{|c|c|c|c|c|}
\hline Sex & $\mathrm{CL}_{\infty}(\mathrm{mm})$ & $K\left(\right.$ year $\left.^{-1}\right)$ & Geographic region & Reference \\
\hline Female & 44 & 0.7 & \multirow[t]{2}{*}{ Southern Portugal } & \multirow[t]{2}{*}{ Ribeiro-Cascalho (1988) } \\
\hline Male & 36 & 0.9 & & \\
\hline Female & 44 & 0.74 & \multirow[t]{2}{*}{ Southern Spain (Gulf of Cadiz) } & \multirow[t]{2}{*}{ Sobrino (1998) } \\
\hline Male & 33 & 0.95 & & \\
\hline Female & $41-44$ & $0.85-0.73$ & \multirow[t]{2}{*}{ Balearic Island } & \multirow[t]{2}{*}{ Guijarro et al. (2009) } \\
\hline Male & $30-3.5$ & $0.8-0.9$ & & \\
\hline Female & 47 & 0.43 & \multirow[t]{2}{*}{ S.E. Spain (Gulf of Alicante) } & \multirow[t]{2}{*}{ Garcia-Rodriguez et al. (2009) } \\
\hline Male & 36 & 0.49 & & \\
\hline Female & 44.4 & 0.74 & \multirow[t]{2}{*}{ Central Tyrrhenian Sea } & \multirow[t]{2}{*}{ Ardizzone et al. (1990) } \\
\hline Male & 33.1 & 0.93 & & \\
\hline Combined & 30.5 & 0.63 & Strait of Sicily & Levi et al. (1995) \\
\hline Female & 40.9 & 0.71 & \multirow[t]{2}{*}{ Strait of Sicily } & \multirow[t]{2}{*}{ Ragonese et al. (2004) } \\
\hline Male & 34.3 & 0.73 & & \\
\hline Female & 47.7 & 0.74 & \multirow[t]{2}{*}{ Ionian Sea } & \multirow[t]{2}{*}{ D’Onghia et al. (1998) } \\
\hline Male & 35.5 & 0.54 & & \\
\hline Female & 37.2 & 0.76 & \multirow[t]{2}{*}{ Ionian Sea (Greek) } & \multirow[t]{2}{*}{ Kapiris et al. (2007) } \\
\hline Male & 33.2 & 0.68 & & \\
\hline Female & 37.2 & 0.52 & \multirow[t]{2}{*}{ Greece } & \multirow[t]{2}{*}{ Anonymous (1998) } \\
\hline Male & 33.7 & 0.62 & & \\
\hline Female & 34.7 & 1.05 & \multirow[t]{2}{*}{ Aegean Sea (Saros Bay) } & \multirow[t]{2}{*}{ Bilgin et al. (2009) } \\
\hline Male & 27 & 1.49 & & \\
\hline Female & 32.3 & 0.77 & \multirow[t]{2}{*}{ Mersin (Turkey) } & \multirow[t]{2}{*}{ Monasirli et al. (2011) } \\
\hline Male & 31.2 & 0.76 & & \\
\hline Female & 38.5 & 0.65 & \multirow[t]{2}{*}{ Terrasini } & \multirow[t]{2}{*}{ Present study } \\
\hline Male & 32.5 & 0.85 & & \\
\hline Female & 40 & 0.6 & \multirow[t]{2}{*}{ Porticello } & \multirow[t]{2}{*}{ Present study } \\
\hline Male & 30 & 0.76 & & \\
\hline Combined & 40 & 0.49 & Morocco & CopeMed II (2011) \\
\hline Combined & 38 & 0.7 & Algeria & CopeMed II (2011) \\
\hline Combined & 40 & 0.89 & Spain 1 & CopeMed II (2011) \\
\hline Combined & 45 & 0.39 & Spain 2 & CopeMed II (2011) \\
\hline
\end{tabular}

year ${ }^{-1}$ and $\mathrm{CL}_{\infty}=30 \mathrm{~mm}, K=0.76$ year $^{-1}$, respectively. The estimated growth parameters of deep-water rose shrimp in the Mediterranean Basin and Atlantic Ocean obtained from other studies are provided in table III for comparison.

Macroscopic ovarian maturity indicated that specimens at stage I could be found throughout the year in both fishing areas, but were found in greatest abundance during the months of September (31.3\%) and July (27.4\%) in Porticello compared to August (33.3\%) and December (35.2\%) in Terrasini (figs. 4 and 5). The lowest 


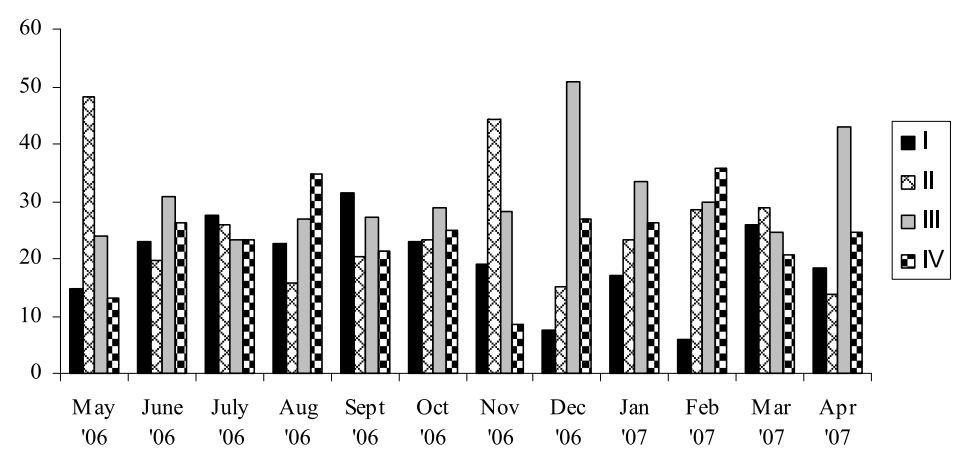

Fig. 4. Percentages of females of Parapenaeus longirostris (Lucas, 1846) in the four stages of maturity at the Porticello sampling site.

number of Stage 1 specimens was observed in February with $6 \%$ and $4.5 \%$ in Porticello and Terrasini, respectively. Stages II and III were present throughout the year and followed similar trends in both fleets. Stage IV specimens, corresponding to the spawning phase, were also observed throughout the year, with pronounced peaks in February (35.7\%) and August (34.8\%) in Porticello, while the lowest numbers were observed in November (8.6\%) and January (15.3\%). In the samples from Terrasini, higher frequencies of stage IV were recorded in February $(47.1 \%)$, September $(35.5 \%)$ and June (35.2\%), while lower frequencies were observed in November $(5.1 \%)$ and January $(15.3 \%)$. The size of females at the first maturity $\left(\mathrm{CL}_{50 \%}\right)$ was 26.6 and $27.8 \mathrm{~mm}$ CL for Porticello and Terrasini, respectively, based on the logistic model (fig. 6). This value corresponds to about 1.9-2.0 years of age according to the previously estimated VBGF on a total fishable lifespan of three years. The overall sex ratio was 0.60 and 0.49 in Porticello and Terrasini, respectively. The sex ratio by size (fig. 7) shows as the percentage of the females increasing constantly from a size of $25 \mathrm{~mm}$ reaching the $100 \%$ in both areas.

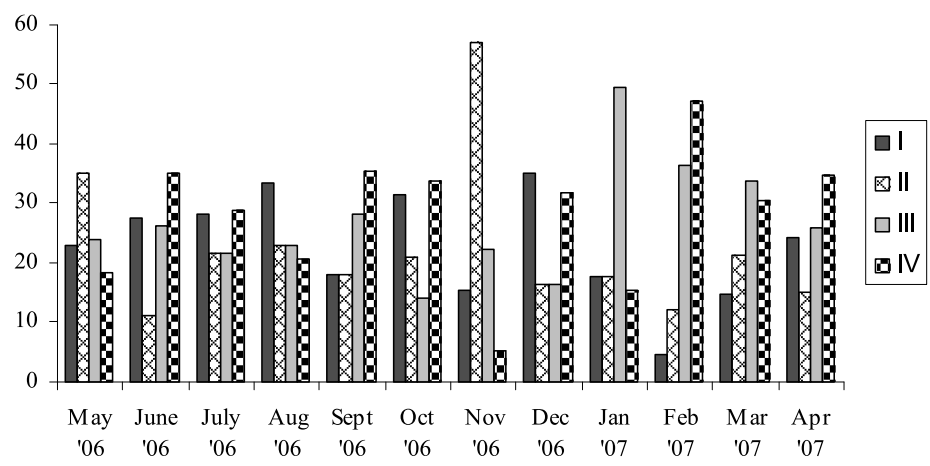

Fig. 5. Percentages of females of Parapenaeus longirostris (Lucas, 1846) in the four stages of maturity at the Terrasini sampling site. 

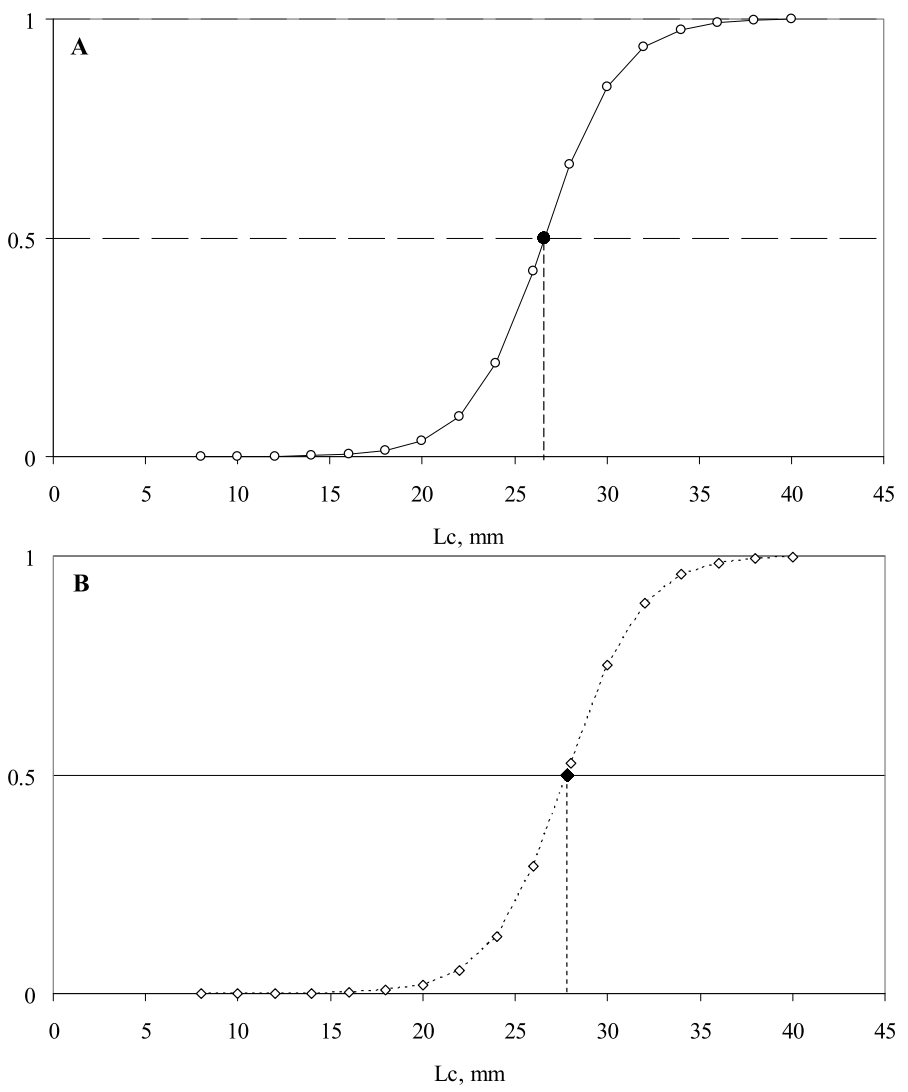

Fig. 6. Observed (open circles) and estimated (solid line; logistic) proportion of mature females of Parapenaeus longirostris (Lucas, 1846) A, Porticello $\left(\mathrm{CL}_{50 \%}=26.61 \mathrm{~mm}\right)$; B, Terrasini $\left(\mathrm{CL}_{50 \%}=\right.$ $27.78 \mathrm{~mm})$.

\section{DISCUSSION}

The analysis of size distributions of Parapenaeus longirostris in both fishing grounds showed that approximately $20 \%$ of the total catch are specimens that are undersized (CL < 20 mm; Council Regulation EC No. 1967/2006 of 21 December 2006). Males were smaller than females, and specimens with small dimensions were mainly captured in autumn and winter. A comparison of the distribution of sizes indicates that Porticello fleets frequently caught smaller specimens compared to Terrasini fleets, likely reflecting the Castellammare shelf closure, the slightly slower growth rate in Porticello, as well as the higher fishing exploitation in the fishing ground there due to the greater fishing capacity. The LFD modes of the Terrasini fishing ground were almost identical to those previously reported by Arculeo et al. (1988) in the same area (Gulf of Castellammare). Due to a lack of information, results were only compared with Terrasini and not with Porticello. 


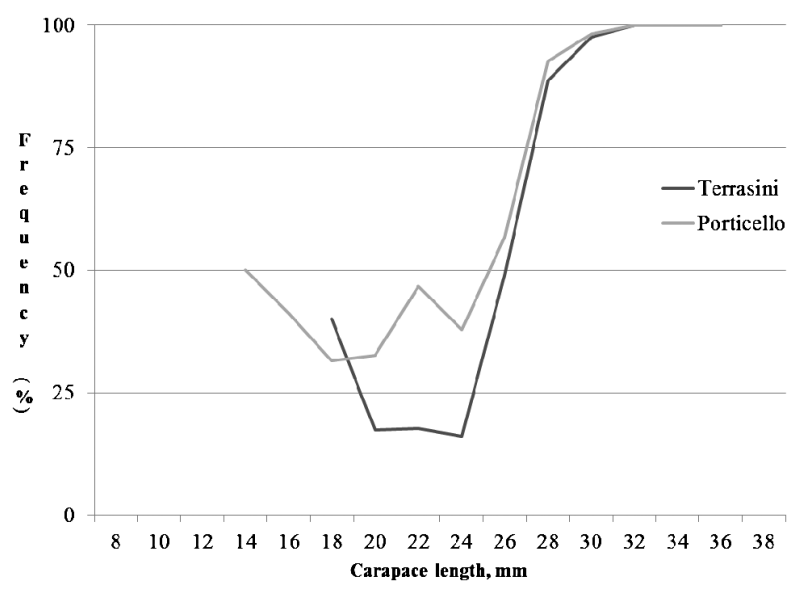

Fig. 7. Sex ratios ((female/females + males $) \times 100)$ of Parapenaeus longirostris (Lucas, 1846) at the Porticello and Terrasini sampling sites.

Our results in the Terrasini fishing ground are quite astonishing, not least because during the last 25 years the mesh size of the cod end progressively increased, reaching $40 \mathrm{~mm}$ diamond during the sampling period and $50 \mathrm{~mm}$ diamond and $40 \mathrm{~mm}$ square mesh in 2010 (Council Regulation EC No. 1967/2006); in any case, it seems that the quite unenforced fishing activities during the last 25 years, have only been able to ensure the reduction of fishing recruits and juveniles, with limited buffer capabilities and a clear strong reduction of the older components.

The largest sizes observed for both sexes were slightly lower than those previously reported by De Ranieri et al. (1988), Auteri et al. (1988), Carbonara et al. (1998) and Levi et al. (1995) from the south Tyrrhenian Sea, in the Strait of Sicily and the Sea of Marmara (Tosunoglu et al., 2008). Conversely, both males and females in the current study were larger in size than those of the Aegean Sea (Tosunoglu et al., 2008). However, sizes were consistent with those reported by Kapiris et al. (2007) from the Greek Ionian Sea. These differences, in general, may be the result of a different overall productivity among the basins, the size of the mesh of net used, the average depth in which specimens were captured and, of course, the state of exploitation of the resource.

VBGF values compared to those reported from other parts of the Mediterranean Sea were similar to those observed from the Ionian Sea (Greek coasts) and the Strait of Sicily, whereas they were slightly different from those of the other part of the Mediterranean Sea (see table III for values and references). However, these values indicate that $P$. longirostris is a fast-growing species, with a fishable lifespan of two years for males and three years for females. Moreover, data from Terrasini are consistent with those previously reported by Arculeo et al. (1988) from the same area. The comparison of all these values is difficult to interpret because 
a greater number of data and, above all, a common standardisation of analysis are necessary to hazard a reasonable conclusion or hypothesis. It seems, however, that the western region of the Mediterranean shows higher values than the eastern region, while values from the central Mediterranean (Sicily Channel and Southern Tyrrhenian Sea) are intermediate. In particular, the Sicily Channel corresponds to the narrow, relatively shallow gateway connecting the large western and eastern Mediterranean basins, playing an important role in the physical and dynamic processes evolving in the entire Mediterranean (Lermusiaux \& Robinson, 2001; Garcia Lafuente et al., 2005; Mejri et al., 2011). If we consider the Mediterranean Sea as a basin in which the western sector differs from the eastern one due to environmental factors (salinity, temperature, productivity and currents, etc.), such factors may influence growth parameters and the consistency of the stock. Of course, we cannot exclude the direct and different effect of the fishing fleet.

Length-frequency analysis indicated three possible age classes in Terrasini and Porticello for females and two possible age classes for males. Although the values of these modes were slightly different, they were reasonably comparable. Data obtained for males and females are consistent with those reported by Kapiris (2007) from the Hellenic Ionian Sea and the Aegean Sea, but not with those of Garcia-Rodriguez et al. (2009) from the Alicante water or Tosunoglu et al. (2008) from the Sea of Marmara and the Aegean Sea.

The parameters of the size-weight relationship estimated in this study suggest a negative allometry for both sexes and are similar to those calculated by other authors in the Mediterranean (Levi et al., 1995) and in the Atlantic (RibeiroCascalho \& Arrobas, 1987; Sobrino \& García, 1994; Sobrino et al., 2005). Analysis of the maturity stages indicates that $P$. longirostris is an asynchronous batch spawner, in which all stages of maturity can be found each month and that all types of oocytes are present in the mature ovary. These observations are in agreement with the data reported by Bianchini et al. (2010) in the Strait of Sicily. Specimens with mature gonads (stage IV) reach two massive spawning peaks, the first one occurring in late winter (February) and the other one during summer (August-September), in which older individuals spawn together with those that are spawning for the first time. These results are partially in agreement with previous observations reported by Arculeo et al. (1992) from the same area, Spedicato et al. (1996) from the Southern Tyrrhenian Sea, De Ranieri et al. (1998), Mori et al. (2000) from the Northern Tyrrhenian and Guijarro et al. (2009) from the Balearic Islands. Conversely, data from the current study show a discrepancy with findings previously reported by Levi et al. (1995) from the Strait of Sicily, Ardizzone et al. (1990) from Central Tyrrhenian and Meriem et al. (2001) from Tunisian waters. Additional differences from our spawning period were also reported by Tom et 
al. (1988) along the Israeli coasts, where $P$. longirostris in superficial water (40$80 \mathrm{~m}$ depth) showed a continuous period of reproduction, while in the deeper water the reproduction period occurred between June and August. Moreover if we compare our results with those recorded from the Atlantic waters by Sobrino \& Garcia (2007) (Gulf of Cadiz), Ribeiro-Cascalho \& Arrobas (1987) from the south of Portugal and Sobrino \& García (1994) from the waters off Morocco, they found two main spawning peaks; the first one in summer and the other one in autumn/winter. These similar spawning peaks may be correlated with the habits of fishing fleets with regards to the seasons and depth at which they operate. In fact, according to Sobrino \& Garcia (2007 and references therein), Tom et al. (1988) and Benchoucha et al. (2008), in the Atlantic Ocean the reproductive behaviour of $P$. longirostris is strongly related to its bathymetric distribution. Specifically, mature females are typically found at greater depths than juvenile females, since temperature and salinity play an important role in ovarian maturation. These events in the areas studied can fluctuate throughout the years as a function of oceanographic conditions. Moreover, according to Arculeo et al. (1995) and Mura \& Cau (1989), a dissimilarity in the reproductive behaviour of $P$. longirostris from different parts of the Mediterranean should not be ruled out and should confirm a strict correlation between the maturation of the gonad and the seasonal flux of solar energy; this could be seen as a general adaptive flexibility of the Mediterranean benthos, reflecting the astonishing diversity of the Mediterranean systems (Margalef, 1985).

With regards to the value of size at first maturity in both areas studied, they were very similar and in agreement with those reported by Ribeiro-Cascalho \& Arrobas (1987) off southern Portugal, Sobrino \& García (1994) from Moroccan Atlantic waters, Garcia-Rodriguez et al. (2009) from the Gulf of Alicante and Gujarro et al. (2009) from the Balearic Islands. Conversely, sizes differed from those previously reported by Crosnier et al. (1970) from the waters off Congo $(22 \mathrm{~mm})$, Sobrino \& Cardenas (1996) from the waters off Angola (21.6 mm) and De Ranieri et al. (1998) from Mediterranean waters ( $21.5 \mathrm{~mm} \mathrm{CL}$ ). These differences may be attributed to differences in contribution of small-sized individuals to the samples obtained in the various areas studied. In any case, maturation of females takes place from the start of the second year of life.

A comparison of the sex ratio by size between the two fishing grounds highlights the more exploited stock of Terrasini, with a considerably lower percentage of females between 20 and $24 \mathrm{~mm}$ CL; although the fishing capacity of Terrasini is lower than that of Porticello, its less extended fishing grounds and the higher mean gross tonnage of its trawlers seem not to be able to ensure a long-term sustainability. 
In conclusion, given the differences found by various authors and considering that the biology and distribution of this species is influenced by environmental parameters, such as temperature, a system to standardise the procedures for collecting and analysing data is needed.

\section{ACKNOWLEDGEMENTS}

This research was supported by Fondi di Ateneo (ex 60\%) and by POR-Sicilia 2000/06 project No. 56. We are grateful to Drs F. Zizzo, M. Toccaceli, M. C. Alessi, O. Marullo for collecting samples and laboratory analysis.

\section{REFERENCES}

ANONYMOUS, 1998. Campagne internazionale de chalutage démersal en Mediterranée (MEDITS). Manuel de protocole. Biologia Marina Mediterranea, 5: 515-572.

Abellò, P., A. Abella, A. Adamidou, S. Jukic-Peladic, P. Maiorano \& M. T. SpediCATO, 2002. Geographical patterns in abundance and population structure of Nephrops norvegicus and Parapenaeus longirostris (Crustacea: Decapoda) along the European Mediterranean coasts. Scientia Marina, 66(Suppl. 2): 125-141.

Abelló, P., F. J. Valladares \& A. CAstellón, 1988. Analysis of the structure of decapod crustacean assemblages off the Catalan coast (North-West Mediterranean). Marine Biology, 98: $39-49$.

Arculeo, M., G. D'AnNa \& S. Riggio, 1988. Valutazione delle risorse demersali nell'area compresa fra Capo Gallo e Capo San Vito (Sicilia Nord Occidentale): risultati delle campagne condotte nel 1985. Atti Seminari UU.OO., Pubblicazione Ministero Margarina Mercantile Consiglio Nazionale delle Ricerche, III: 1413-1451.

Arculeo, M., G. Galioto \& A. Cuttitta, 1992. Aspetti riproduttivi in Parapenaeus longirostris (Crustacea, Decapoda) nel Golfo di Castellamare (Sicilia N/W). Biologia Marina, (Supplemento Notiziario Società Italiana di Biologia Marina), 1: 307-308.

Arculeo, M., G. Payen, A. Cuttitta, G. Galioto \& S. Riggio, 1995. A survey of ovarian maturation in a population of Aristeus antennatus (Crustacea: Decapoda). Animal Biology, 4: 13-18.

Ardizzone, G. D., M. F. Gravina, A. Belluscio \& P. Schintu, 1990. Depth-size distribution pattern of Parapenaeus longirostris (Lucas, 1846) (Decapoda) in the central Mediterranean Sea. Journal of Crustacean Biology, 10: 139-147.

Ben Meriem, S., R. Fehri-Bedoul \& H. Gharbi, 2001. Size at maturity and ovigerous period of the pink shrimp Parapenaeus longirostris (Lucas, 1846) in Tunisia. Crustaceana, 74: 39-48.

Benchoucha, S., A. Berraho, H. BAzAiri, I. Katara, S. Benchrifi \& V. D. VAlaVAnis, 2008. Salinity and temperature as factors controlling the spawning and catch of Parapenaeus longirostris along the Moroccan Atlantic Ocean. Hydrobiologia, 612: 109-123.

Bianchini, M. L., L. Di Stefano \& S. Ragonese, 2010. Reproductive features of the deepwater rose shrimp, Parapenaeus longirostris (Crustacea: Penaeidae), in the Strait of Sicily. Medititerranean Marine Science, 11: 81-92.

BILgin, S., O. OzEN, A. ISMEN \& U. OzEKINCI, 2009. Bathymetric distribution, seasonal growth and mortality of the deep-water rose shrimp Parapenaeus longirostris (Decapoda: Penaeidae) in an unexploited stock in Saros Bay, Aegean Sea. Journal of Animal and Veterinary Advances, 8: $2404-2417$. 
Carbonara, P., T. Silecchia, G. Lembo \& M. T. Spedicato, 1988. Accrescimento di Parapenaeus longirostris (Lucas, 1846) nel Tirreno Centro-Meridionale. Biologia Marina Mediterranea, 5: 665-667.

CBI, 2010. CBI Market Information Database: the EU market for shrimps and prawns. Available online at: http://www.cbi.eu/system/files/marketintel/201020-20Shrimps20and20Prawns1.pdf.

COPEMED II, 2011. Report of the First meeting of the Working Group on Parapenaeus longirostris stock for Algeria, Morocco and Spain (GSAs 01, 02, 03 and 04 of the GFCM). CopeMed II ArtFiMed Technical Documents No. 19 (GCP/INT/028/SPA-GCP/INT/006/EC), Málaga: 170.

Crosnier, A., A. Fontana, J. C. Le Guen \& J. P. Wise, 1970. Ponte et croissance de la crevette Peneide Parapenaeus longirostris (Lucas) dans la region de Pointe-Noire (Republique du Congo). Cahiers ORSTOM. Serie Oceanographie, 8: 89-102.

DE RANIERI, S., M. Mori \& M. Sbrana, 1998. Preliminary study on the reproductive biology of Parapenaeus longirostris (Lucas) off the northern Tyrrhenian Sea. Biologia Marina Mediterranea, 5: 710-712.

D’Onghia, G., A. Matarrese, P. Maiorano \& F. Perri, 1998. Valutazione di Parapenaeus longirostris (Lucas, 1846) (Crustacea, Decapoda) nel Mar Ionio. Biologia Marina Mediterranea, 5: 273-283.

Fischer, W., M. L. BAUChOT \& M. SCHNEIDER, 1987. Fiches FAO d'identification des espèces pour les besoins de la pêche. (Révision 1). Mediterranée et Mer Noire. Zone de pêche 37.2. vol. II Vertébrés. Publication préparée par la FAO (Projet GCP/INT/422/EEC): 761-1530. (FAO, Rome).

Froglia, C., 1982. Contribution to the knowledge of the biology of Parapenaeus longirostris. Quaderni del laboratorio di Tecnologia della Pesca, 3: 163-168.

Garcia lafuente, J., J. M. Vargas, F. A. Criadogarcia, J. Delgado \& S. Mazzola, 2005. Assessing the variability of hydrographic processes influencing the life cycle of the Sicilian Channel anchovy, Engraulis encrasicolus, by satellite imagery. Fisheries Oceanography, 14: $32-46$.

Garcia-Rodriguez, M., J. L. Pérez \& E. Barcala, 2009. Some biological aspects of Parapenaeus longirostris (Lucas, 1846) (Decapoda, Dendrobranchiata) in the gulf of Alicante (S.E. Spain). Crustaceana, 82: 293-310.

Gayanilo, F. C., P. Sparre \& D. Pauly, 2005. The FAO-ICLARM stock assessment tools II (FiSAT II) reference manual: 1-168. (FAO Computerized Information Series, Fisheries, 8, Revised version). (FAO, Rome).

Guijarro, B., E. Massuti, J. Moranta \& J. E. CARTes, 2009. Short spatio-temporal variations in the population dynamics and biology of the deep-water rose shrimp Parapenaeus longirostris (Decapoda: Crustacea) in the western Mediterranean. Scientia Marina, 73: 183-197.

Holthuis, L. B., 1987. Crevettes. In: W. Fischer, M. Schneider \& M. L. Bauchot (eds), Fiches FAO d'identification des especes pour les besoins le la peche. Méditerranée et Mer Noire. Zone de peche 37. Vegetaux et invertebres: 271-272.

ICES, 2010. Report of the Workshop on crustaceans (Aristeus antennatus, Aristaeomorpha foliacea, Parapenaeus longirostris, Nephrops norvegicus) maturity stages (WKMSC), 19-23 October 2009, Messina, Italy. ICES CM 2009/ACOM: 46.

Kapiris, K., O. KasaliCA, D. KLaOudatos \& M. DJurovic, 2013. Contribution to the biology of Parapenaeus longirostris (Lucas, 1846) in the South Ionian and South Adriatic Sea. Turkish Journal of Fisheries and Aquatic Sciences, 13: 647-665.

Kapiris, K., C. Mytilineou, S. Kavadas \& F. CapezzUto, 2007. Age and growth of the deepwater rose shrimp Parapenaeus longirostris in the Hellenic Ionian Sea. Rapport Commission international Mer Méditeranéen, 38: 510.

Keys, A. B., 1928. The weight-length relationship in fishes. Proceedings of the National Academy of Sciences of the United States of America, 14: 922-925. 
KING, M., 2007. Fisheries biology, assessment and management. (Blackwell, Oxford).

Lermusiaux, P. F. J. \& A. R. Robinson, 2001. Features of dominant mesoscale variability, circulation pattern and dynamics in the Strait of Sicily. Deep-Sea Research, 48: 1953-1997.

Levi, D., M. G. Andreoli \& R. M. Giusto, 1995. First assessment of the rose shrimp, Parapenaeus longirostris (Lucas 1846), in the central Mediterranean. Fishery Research, 21: 375-393.

Ligas, A., P. SARTor \& F. Colloca, 2011. Trends in population dynamics and fishery of Parapenaeus longirostris and Nephrops norvegicus in the Tyrrhenian Sea (NW Mediterranean): the relative importance of fishery and environmental variables. Marine Ecology, 32(Suppl. 1): 25-35.

Lo Brutto, S., T. Maggio \& M. Arculeo, 2013. Isolation By Distance (IBD) signals in the deep-water rose shrimp Parapenaeus longirostris (Lucas, 1846) (Decapoda, Panaeidae) in the Mediterranean Sea. Marine Environmental Research, 90: 1-8.

Manasirli, M., D. Avsar \& H. Yeldan, 2011. Growth, mortality rate and exploitations rate of the deep-water rose shrimp (Parapenaeus longirostris) in the Babadillimani Bight (SilifkeMersin). Ekoloji, 20: 38-44.

MARGALEF, R., 1985. Key environmental: Western Mediterranean. (Pergamon Press, Oxford).

MEDITS, 2002. Final report 2000-2001 RAP2000-01_VOL1, 25/05/2002, 248 pp. Sibm website. Available online at http://www.sibm.it/MEDITS\%202011/principaleprogramme.htm (accessed 2 June 2012).

Mejri, R., M. Arculeo, O. K. Ben Hassine \& S. Lo Brutto, 2011. Genetic architecture of the marbled goby Pomatoschistus marmoratus (Perciformes, Gobiidae) in the Mediterranean Sea. Molecular Phylogenetics and Evolution, 58: 395-403.

Mori, M., M. Sbrana \& S. De Ranieri, 2000. Reproductive biology of female Parapenaeus longirostris (Crustacea, Decapoda, Penaeidea) of the north Thyrrenian Sea (western Mediterranean). Atti Società Toscana Scienze naturali Memorie, 107(B): 1-6.

Mura, M. \& A. CAU, 1989. Sul dimorfismo sessuale e sex ratio in Aristeus antennatus (Risso, 1816). Oebalia, 15: 811-814.

Mytilineou, C., C. Y. Politou, C. Papaconstantinou, S. Kavadas, G. D’Onghia \& L. SION, 2005. Deep-water fish fauna in the Eastern Ionian Sea. Belgian Journal of Zoology, 135: 229-233.

PAULY, D. \& J. L. MUNRO, 1984. Once more on the comparison of growth in fish and invertebrates. ICLARM Fishbyte, 2: 21.

PÉRÈs, J. M. \& J. PICARD, 1964. Nouveau Manuel de Bionomie Benthique de la Mer Mediterranée. Recueil des Travaux de la Station Marine d'Endoume, Bull. N. 31, fasc. n. 47: 5-137.

Ragonese, S., M. G. Andreoli, G. Bono, G. B. Giusto, P. Rizzo \& G. Sinacori, 2004. Overview of the available biological information on demersal resources of the Strait of Sicily. GCP/RER/010/ITA/MSM-TD-02. MedSudMed Technical Documents, 2: 67-74.

RELINI, G., 2000. Demersal trawl surveys in Italian Seas: a short review. Actes de Colloques IFREMER, 26: 76-93.

Relini, G., P. CARpentieri \& M. Murenu, 2008. Manuale di Istruzioni Medits (Medits Instruction Manual). Biologia Marina Mediterranea, 15: 1-78.

Ribeiro-Cascalho, A. \& I. Arrobas, 1987. Observations on biology of Parapenaeus longirostris (Lucas, 1846) from the south coast of potugal. Investigación Pesquera, 51: 201-212.

Rinelli, P., D. Giordano, F. Perdichizzi, S. Greco \& S. Ragonese, 2005. Trawl gear selectivity on the deep-water rose shrimp (Parapenaeus longirostris Lucas, 1846) in the Southern Tyrrhenian Sea (central Mediterranean). Cahiers de Biologie Marine, 46: 1-7.

Rinelli, P., S. Ragonese, P. Consoli, G. Florio, T. Romeo, F. Perdichizzi \& S. Greco, 2004. Monitoring no-taken areas: the cases of the Gulfs of Castellammare and Patti (Northern coasts of Sicily). Biologia Marina Mediterranea, 11: 82-87. 
Sbrana, M., P. SARTOR \& P. Belcari, 2003. Analysis of the factors affecting crustacean trawl fishery catch rates in the northern Tyrrhenian Sea (western Mediterranean). Fisheries Research, 65: 271-284.

Sobrino, I. \& E. De CÁRdenas, 1996. Análisis de los resultados obtenidos para la Gamba Blanca (Parapenaeus longirostris, Lucas 1846) durante la Campaña "Angola 8911". In: O. LLINÁs, J. A. GonZÁlez \& M. RuedA (eds.), Monografía. Instituto Canario de Ciencias Marinas: 356. (Instituto Canario de Ciencias Marinas, Telde (Las Palmas de Gran Canaria)).

Sobrino, I. \& T. GARCÍA, 1994. Biology and fishery of the deep-water Rose shrimp, Parapenaeus longirostris (Lucas, 1846) from the Atlantic Moroccan coast. Scientia Marina, 58: 299-305.

— — \& — - 2007. Reproductive aspects of the rose shrimp Parapenaeus longirostris (Lucas, 1846) in the Gulf of Cadiz (southwestern Iberian Peninsula). Boletin Instituto Espanol de Oceanografía, 23: 57-71.

Sobrino, I., C. Silva, M. Sbrana \& K. Kapiris, 2005. A review of the biology and fisheries of the deep-water rose shrimp, Parapenaeus longirostris, in European Atlantic and Mediterranean waters (Decapoda, Dendrobranchiata, Penaeidae). Crustaceana, 78: 1153-1184.

Spedicato, M. T., G. Lembo, P. Carbonara \& T. Silecchia, 1998. Valutazione delle risorse demersali dal Fiume Garigliano a Capo Suvero. Biologia Marina Mediterranea, 5: 64-73.

Spedicato, M. T., G. Lembo, T. Silecchia \& P. Carbonara, 1996. Distribuzione e biologia di Parapenaeus longirostris (Lucas, 1846) nel Tirreno centro-meridionale. Biologia Marina Mediterranea, 3: 579-581.

STECF, 2013. Scientific, Technical and Economic Committee for Fisheries: assessment of Mediterranean Sea stocks part I (STECF 13-22), EUR 26329 EN, JRC 86087. (Publications Office of the European Union, Luxembourg).

TAYLOR, C. C., 1962. Growth equation with metabolic parameters. Journal du Conseil International pour l'Exploration de la Mer, 27: 270-286.

Tom, M., M. Gorem \& M. Ovadia, 1988. The benthic phases of life cycle of Parapenaeus longirostris (Crustacea, Decapoda, Penaeidae) along the Mediterranean coast of Israel. Hydrobiologia, 169: 339-352.

Tosunoglu, Z., M. C. Deval, T. Uluturk \& T. Katagan, 2008. A comparison of the size structure of Parapenaeus longirostris (Lucas, 1846) (Decapoda, Penaeidae) between populations in the Sea of Marmora and in the Aegean Sea. Crustaceana, 81: 477-486.

Ungaro, N. \& R. Gramolini, 2006. Possible effect of bottom temperature on distribution of Parapenaeus longirostris (Lucas, 1846) in the Southern Adriatic (Mediterranean Sea). Turkish Journal of Fisheries and Aquatic Sciences, 6: 109-116.

First received 17 January 2014.

Final version accepted 5 June 2014. 